\title{
ROSYJSKIE CZASOWNIKI RUCHU WIROWEGO W ŚWIETLE METAFORY POJĘCIOWEJ
}

\author{
RUSSIAN VERBS OF CIRCULAR MOTION \\ IN THE LIGHT OF THE CONCEPTUAL METAPHOR
}

\author{
ANDRZEJ NARLOCH
}

\begin{abstract}
AвSTRACT. In recent years linguistic studies have laid great emphasis on the semantic side of linguistic expressions. The aim of this paper is to introduce and describe the term "circular motion" viewed from the perspective of the conceptual metaphor in Russian. It describes the process of creating such metaphors based on the notions of source and target domains.

Keywords: conceptual metaphor, circular motion, Russian verbs, semantic

Andrzej Narloch, Uniwersytet im. Adama Mickiewicza w Poznaniu, Poznań - Polska, andrzej.narloch@amu.edu.pl
\end{abstract}

ORCID ID: 0000-0001-5225-289X

W ostatnich dziesięcioleciach badania językoznawcze są skoncentrowane $\mathrm{w}$ dużej mierze na procesach poznania rzeczywistości przez pryzmat języka, jego struktury oraz wzajemnych relacji język - kultura. W języku, a zwłaszcza w skonwencjonalizowanych połączeniach wyrazowych, znajduje swoje odbicie długotrwały proces rozwoju kultury danego narodu, wzorców myślenia, wartości, stereotypów, mitów, obyczajów, tradycji itd. Odzwierciedlony w języku sposób widzenia świata stanowi fragment pewnej większej struktury określanej językowym obrazem świata. Ten obraz jest swego rodzaju projekcją rzeczywistości przepuszczoną przez filtr naszej świadomości i interpretacji otaczających zjawisk i przedmiotów.

Specyficzną interpretację świata odnajdujemy również w przenośnych użyciach czasowników ruchu wirowego (obrotowego). Ruch wirowy posiada bogate konotacje kulturowe. W świadomości użytkowników języka niesie ze sobą duży ładunek energetyczny. Wirujący obiekt (przedmiot, człowiek) uzewnętrznia posiadanie energii kinetycznej, właściwości magiczne. Na przykład rosyjskie czasowniki ze znaczeniem jednorazowego niepełnego obrotu обернуться, оборотиться wyrażają przenośnie transformację ciała, przedmiotu w inny przedmiot bądź ciało (człowieka, zwierzę, mitycznego stwora), co potwierdzają dane słownikowe, por.: обернуться, 'превратиться в (...) кого, что-л. при помощи колдовства' [Кузнецов 1998: 666], оборотиться '[...] 
волшебством превращаться из одного существа или предмета в другое существо или в другой предмет' [Ефремова 2000: 1084].

Niniejsze opracowanie jest próbą prezentacji rosyjskich czasowników ruchu okrężnego (глаголы вращения) w świetle metafory pojęciowej. Głównym zadaniem artykułu jest prezentacja metaforycznych użyć czasowników w ujęciu George'a Lakoffa i Marka Johnsona. Metafory ruchu wirowego wyrażają aktywność ludzką zarówno w sferze działalności fizycznej, jak i uczuciowej. Ruch ten stanowi przeciwwagę dla bezruchu, za którym kryje się najczęściej brak emocji, obojętność, stagnacja.

System czasowników ruchu wirowego jest częścią szerszej grupy czasowników ruchu i interesującą grupą leksykalno-semantyczną. Niektóre z czasowników omawianego ruchu wyrażają równocześnie znaczenie ruchu postępowego (катиться, кататься). Różnią się one od innych czasowników tej grupy strukturą argumentową, i, jak twierdzi Wiktorija Aleksiejewna Krugliakowa i Jekaterina Władimirowna Rachilina, dla ich semantyki nieistotne są początkowy i końcowy punkt, kierunek, sposób i środowisko ruchu [Kpyглякова, Рахилина 2010: 242]. Zgodnie ze słowami Krugliakowej, rosyjski system tworzy osiem czasowników ruchu okrężnego. Należą do nich: $b p a-$ щаться, крутиться, вертеться, кружить, кружиться, катиться, кататься и виться [Круглякова 2010: 30].

Przed przystąpieniem do opisu metafor pojęciowych celowe wydaje się krótkie omówienie struktury semantycznej wyrazu. W niektórych ujęciach metodologicznych centralną jednostką badań jest znaczenie jako bazowa kategoria semantyki. Tym niemniej za różnymi podejściami do analizy pojęcia znaczenia kryją się określone koncepcje. Wypływające ze strukturalizmu składnikowe podejście do opisu znaczenia słowa na pierwszy plan wysuwa określone komponenty (archisemy i semy dyferencjalne). Struktura znaczeniowa słowa określana jest przy pomocy odpowiedniego zestawu składników. Na przykład czasownik идmu składa się z następujących elementów znaczenia: 'движение', 'перемещение', 'однонаправленность движения'. Zupełnie odmienne podejście prezentuje współczesna semantyka kognitywna, która strony treściowej wyrażeń językowych szuka w szeroko rozumianym doświadczeniu, którego odzwierciedleniem są struktury prototypowe, domeny pojęciowe czy ramy interpretacyjne [Tokarski 2013: 29]. W takim przypadku znaczenie określa się jako pojęcie, myśl lub ideę, którym przypisuje się charakter psychologiczny. Zgodnie ze słowami Ryszarda Tokarskiego:

Za rozwiniętą teorią konotacji semantycznych kryje się założenie, iż w obrębie całościowego modelu znaczenia konkretnej jednostki słownej, na wzór nowszego sposobu postrzegania budowy pojęcia, istnieje hierarchia komponentów, a kontekstowe użycie słowa, analogicznie jak w ujęciach kognitywnych, jednoznacznie pokazuje otwartą strukturę znaczenia [Tokarski 2013: 29]. 
W otwartej strukturze znaczenia dużą rolę odgrywa metaforyzacja. Natomiast istotne miejsce $\mathrm{w}$ metaforyzacji prezentowanych czasowników zajmuje oś obrotu, gdyż niejednokrotnie właśnie ona, jako centralny punkt, wokół którego odbywa się ruch, jest bazą przenośnego użycia. Również z semantycznego punktu widzenia oś obrotu pełni znaczącą rolę, co podkreślają Krugliakowa i Rachilina, uznając ją za fundamentalny parametr opisu leksykalno-semantycznego, który może być wyrażany poprzez obrót wokół własnej osi (np. bączek) lub wokół innego obiektu (np. elektron wokół jądra atomu) [Круглякова, Рахилина 2010: 242].

Wracając do metafory, należy stwierdzić, że tkwi ona w systemie pojęciowym człowieka. Zdaniem Lakoffa i Johnsona, metafory przenikają całe nasze życie, a nasze działania mają charakter metaforyczny. Jak uważają wymienieni autorzy, ,"pojęcia metaforyczne charakteryzujące te działania nadają strukturę naszej obecnej rzeczywistości" [Lakoff, Johnson 1988: 173].

W wyniku tego decydują one o tym, jak widzimy świat i jak działamy. Pojęcie metafory konceptualnej (pojęciowej) wprowadzili do obiegu językowego wspominani wyżej Lakoff i Johnson. Jednocześnie teoria metafory pojęciowej podlega różnym transformacjom i modyfikacjom. Do grona badaczy zgłębiających i rozwijających teorię metafory należy zaliczyć Ivora Armstronga Richardsa, Maxa Blacka, Olivera Jäkela, Johna Roberta Taylora, Ryszarda Tokarskiego, Jerzego Bartmińskiego i in. Metafora jest skomplikowanym zjawiskiem, które w praktyce przenika nie tylko język, lecz również kulturę i otaczający nas świat. Jako fenomen świadomości przejawia się ona, zgodnie ze stwierdzeniem Eduarda Władimirowicza Budajewa, nie tylko w języku, lecz również w myśleniu, i w działaniu [Будаев 2007: 17]. Metafory to swego rodzaju uniwersalia świadomości, pozwalające człowiekowi lepiej rozumieć i interpretować otaczającą rzeczywistość. Przenikają one język tak bardzo, że niekiedy użytkownik nie uświadamia sobie metaforycznego źródła wielu wyrażeń. Jak twierdzą Lakoff i Johnson, „istotą metafory jest rozumienie i doświadczanie pewnego rodzaju rzeczy w terminach innej rzeczy" [Lakoff, Johnson 1988: 27].

Ci sami autorzy, opierając się na kryterium poznawczym, wyróżniają trzy typy metafor: strukturalne, ontologiczne i orientacyjne. Prezentowana analiza dotyczy metafor strukturalnych i ontologicznych, w których „domena źródłowa nakłada na domenę docelową określoną strukturę metaforyczną za pośrednictwem odwzorowań, które określają metaforę" [Kövecses 2011: 194].

W kognitywnym rozumieniu metafora składa się z dwóch elementów - domeny źródłowej i domeny docelowej, które w ludzkim umyśle ulegają scaleniu, zestawieniu na podstawie pewnych podobieństw. Odwołam się do przytoczonej przez Zoltána Kövecsesa metafory ŻYCIE TO PODRÓŻ. Człowiek w swoim codziennym funkcjonowaniu widzi swoje życie przez pryzmat podróży. W swoich wypowiedziach użytkownicy języka mówią, że 
[...] nie mają poczucia żadnego kierunku w życiu, że muszą przez wiele przechodzić, że zajdą daleko $\mathrm{w}$ życiu, że część $\mathrm{z}$ nich miała łatwy start $\mathrm{w}$ życiu, a inni niosą ze sobą ciężki bagaż, że są na rozdrożach i że oglądając się wstecz, widzą wyboistą drogę, a także, że są zdecydowali osiągnąć swój cel [Kövecses 2011: 176].

Kövecses tłumaczy posługiwanie się pojęciem życia przez pryzmat podróży tym, że powyższe stwierdzenia językowe, mówiące o życiu, prezentują głębszą zależność między pojęciami „życie” i „podróż”. Możemy dopatrzeć się tutaj systemowego charakteru tej zależności, opartego na konwencjonalności, funkcjach poznawczych i pewnym poziomie uogólnienia. Przedstawiona przez Kövecsesa odpowiedniość pomiędzy poszczególnymi elementami wzajemnej relacji „ż̇ycie" - „podróż" wygląda następująco:

$\begin{array}{lll}\text { PODRÓż } & \rightarrow & \text { ŻYCIE } \\ \text { podróżny } & \rightarrow & \text { żyjący } \\ \text { podróżowanie/ruch (ku celowi podróży) } & \rightarrow & \text { prowadzenie życia z celem } \\ \text { cel podróży } & \rightarrow & \text { cel życia } \\ \text { przeszkody (na drodze do celu) } & \rightarrow & \text { trudności życiowe } \\ \text { przemierzony dystans } & \rightarrow & \text { poczynione postępy } \\ \text { droga wiodąca do celu } & \rightarrow & \text { sposób na życie } \\ \text { wybór drogi do celu } & \rightarrow & \text { życiowe wybory }\end{array}$

Zaprezentowany schemat odpowiedniości poszczególnych relacji wykazuje, że elementy domeny PODRÓŻ mają swoje odpowiedniki w domenie docelowej ŻYCIE. Jest to zestaw odwzorowań między domenami. Połączenie dwóch pojęć $\mathrm{w}$ akcie mowy lub procesie umysłowym następuje $\mathrm{w}$ toku zamiany jednej domeny (ramy pojęciowej) innym znaczeniem (inną domeną).

Zapotrzebowanie na metafory ze strony języka, umysłu ludzkiego jest niezaprzeczalne, ponieważ metafora służy do nazywania tych zakresów aktywności ludzkiej, które do tej pory nie miały wyraźnego odwzorowania językowego i, będąc z reguły bardziej lub mniej abstrakcyjnym pojęciem, nie posiadały właściwego odpowiednika do nazwania określonej idei, myśli, procesu, działalności. Dlatego najczęściej mamy do czynienia z wykorzystywaniem domen źródłowych opartych na ludzkim fizyczno-motorycznym (somatycznym) doświadczeniu osadzonym w otaczającej rzeczywistości i ich projekcją do domeny docelowej cechującej się znacznie większym poziomem abstrakcji. Z tego powodu metafora czyni pojęcia abstrakcyjne bardziej przystępnymi i zrozumiałymi, a główny wektor przeniesienia metaforycznego jest zwrócony od konkretnego do abstrakcyjnego, od materialnego do duchowego [Маслова 2001: 90]. Amerykański językoznawca Julian Jaynes również odnotował, że abstrakcyjne koncepty tworzone są za pomocą konkretnych metafor [Jaynes 1976: 50]. Oczywiście odwzorowanie opiera się na podstawie

${ }^{1}$ Przykład zaczerpnięty z pracy Z. Kövecsesa [2011: 176]. 
wspólnych cech i właściwości obu ram pojęciowych (domen). W wyniku ich połączenia następuje zlanie się abstrakcyjnego pojęcia i konkretnego przedmiotu, zjawiska, czynności. Dlatego metafora to sposób ujmowania świata, który wykorzystuje wcześniej zdobytą wiedzę i doświadczenie do tworzenia nowych ujęć i sądów o świecie. Wartość metafory, jak twierdzi Walentyna Awraamowna Masłowa, polega również na tym, że

[...] она соизмеряет разные сущности, пропуская их через человека, соизмеряя мир с человеческим масштабом знаний и представлений, с системой культурнонациональных ценностей, т.е. человек здесь [...] мера всех вещей: ручей шепчет, совесть заговорила, надежда проснулась и т.д. Таким образом, метафора по своей природе антропометрична, а сама способность мыслить метафорически есть черта собственно homo sapiens, значит, постижение метафоры есть в какойто мере постижение человеком самого себя [Маслова 2001: 90].

Natomiast Jelena Władimirowna Prikazczikowa uważa, że metafora „как важный инструмент структурной характеристики категоризации позволяет нам сопоставлять друг с другом несовместимые категории, т.е. представлять объекты одной категории в терминах другой" [Приказчикова 2009: 136].

To człowiek z różnorodnych typów podobieństwa wybiera bardziej lub mniej świadomie ten, który następnie znajduje swoje odwzorowanie w języku. Dlatego metafora łamie logiczne granice porządku obiektów otaczającego świata, a zatem łamie istniejącą kategoryzację [Рикёp 1990: 442]. Jaynes, proponując swoją hipotezę o historycznej dynamice asymetrii funkcjonalnej mózgu, widział współzależność między rozwojem świadomości i zdolnością człowieka do metaforyzacji [Jaynes 1976: 50]. Jego zdaniem, metafora to sposób poszerzenia naszego rozumienia świata, natomiast metaforyzacja to jeden z rezultatów ewolucji świadomości.

Przedstawimy zatem na przykładzie rosyjskich czasowników ruchu wirowego, z jakiego typu relacjami metaforycznymi mamy do czynienia i na jakie obszary działalności ludzkiej one wkraczają. Oczywiście, nie podamy wszystkich możliwych przykładów metaforyzacji, dlatego skupimy się na niektórych egzemplifikacjach odtwarzających mechanizm powstawania metafor.

Metaforę pojęciową UCZUCIA TO RUCH WIROWY zaprezentujemy z wyszczególnieniem odpowiedniości pomiędzy poszczególnymi elementami wzajemnej relacji "miłość" - „ruch wirowy”. W przytoczonych poniżej przykładach zauważamy różne aspekty mówienia o miłości za pośrednictwem czasowników кружиться, кружить:

(1) Он встречает женщин, открыто улыбающихся ему, его славе, его счастливой юности, - женщин прекрасных и ждущих столь же прекрасной любви. Кружится голова. 
(2) От запаха любви кружится голова, И возникают вдруг слова, слова, слова [...].

(3) У нее кружится голова от этих бесконечных поцелуев.

(4) От любой смазливенькой блондинки у тебя кружится голова!

(5) Кружить голову богатым барыням и молодым девушкам не мое дело [...].

(6) Это сейчас видно, что человек солидный, который не хочет кружить голову девочке понапрасну, а обращается к матери и $[\ldots]^{2}$.

Powyższe przykłady pozwalają na odnotowanie ścisłego związku między uczuciami (miłością) a ruchem wirowym. Przedmiotem (obiektem) takiego ruchu staje się głowa. Głowa, podobnie jak serce, w wielu kulturach uważana jest za miejsce (ujęte w kategoriach pojemnika) do "przechowywania” uczuć, rozumianych jako przedmiot. Zastosowana metafora ruchu wirowego, obejmującego głowę, czyli siedzibę rozumu, pozbawia człowieka racjonalnego myślenia, prowadzi niejako do paraliżu sfery racjonalnej (rozumowej), a uaktywnia jednocześnie drugą aktywność - uczuciową. Zderzają się tutaj dwa przeciwstawne pierwiastki - racjonalny (logiczny, rozumowy) i uczuciowy (emocjonalny, psychiczny). Ten ostatni aktywizuje sama metafora. W systemie pojęciowym człowieka „wprawianie” w ruch okrężny obiektu wokół własnej osi wyraża znaczenie pozbawiania tego obiektu kontroli nad sobą (вскружить голову кому-л.). Taka utrata kontroli nad sferą racjonalną, to triumf uczuć nad logicznym myśleniem. Jest to jedna ze sfer doświadczeniowych, opartych na postrzeganiu ruchu wirowego jako elementu pozbawiającego człowieka zdolności panowania nad uczuciami, a oparta jest na fizycznej płaszczyźnie doświadczeniowej. Niemniej jednak natrafiamy również na inną sferę doświadczeniową zakładającą, że jej źródłem, jak już wspominałem powyżej, stają się uczucia. Pojawienie się silnych uczuć, co wiąże się fizycznie z przyspieszonym biciem serca, zwiększonym ciśnieniem krwi, prowadzi do powstania $\mathrm{w}$ mniejszym lub większym stopniu zaburzeń $\mathrm{w}$ prawidłowym funkcjonowaniu organizmu, przejawiających się w odczuwaniu ruchu (wirowego) własnego ciała (głowy) w przestrzeni lub poruszania się otaczających przedmiotów. Zapewne nie jest tak, że mamy tu do czynienia tylko i wyłącznie z iluzją ruchu wirowego. Fizyczna sfera doświadczeniowa zdaje się potwierdzać takie przypadki, co znajduje odpowiednie odbicie w wyrażeniach językowych.

Istotną rolę, jak twierdzą Lakoff, Johnson, odgrywa rozróżnienie między doświadczeniem, a sposobem, w jaki je konceptualizujemy. Podłoże metafor może mieć charakter fizyczny, emocjonalny, społeczny, umysłowy i in. Tym niemniej, wymienieni autorzy, twierdzą, że „najczęściej konceptualizujemy

2 Przykłady zastosowania metafor pojęciowych z czasownikami ruchu wirowego zostały zaczerpnięte z Narodowego Korpusu Języka Rosyjskiego [zob. Национальный корпус русского языка]. 
zjawiska niefizyczne w terminach fizycznych - to znaczy, konceptualizujemy zjawiska mniej wyraźnie zarysowane za pośrednictwem zjawisk bardziej wyraźnie zarysowanych" [Lakoff, Johnson 1988: 84].

W niektórych metaforach możemy upatrywać społeczne podłoże pojęć metaforycznych, co wynika z dziedziny doświadczenia, w której ją postrzegamy. Przytoczę kilka przykładów:

(7) Вокруг меня скоро будет крутиться уйма девушек.

(8) Я не собираюсь постоянно крутиться вокруг девушки, которой неинтересно быть со мной.

(9) Если мужчина постоянно „крутиться" около девушки, значит ему нечем заняться и она цель его жизни.

Powyższe wyrażenia opierają się na naszym codziennym doświadczeniu wyobrażeniowym. Jeśli człowiek jest zainteresowany uczuciowo (emocjonalnie) innym człowiekiem bądź zakochał się, to społeczne osadzenie tego doświadczenia opiera się na zwyczajowym obrazie człowieka będącego w pobliżu drugiego człowieka, chodzącego blisko niego, wokół niego. W ludzkim doświadczeniu powstała $\mathrm{w}$ naturalny sposób struktura modelu „miłość to ruch obrotowy". W związku z tym możemy pokusić się o przedstawienie odpowiedniości pomiędzy poszczególnymi elementami wzajemnej relacji „miłość" - „ruch wirowy":

$\begin{array}{lll}\text { RUCH WIROWY } & \rightarrow & \text { MIŁOŚĆ } \\ \text { obiekt na osi obrotu } & \rightarrow & \text { obiekt miłości } \\ \text { wirujący przedmiot } & \rightarrow & \text { osoba zakochana } \\ \text { wirowanie } & \rightarrow & \text { uczucie miłości }\end{array}$

Taka motywacja nie wzbudza wątpliwości, gdyż, jak pokazują przykłady z innych języków, podobny typ konceptualizacji stanu uczuciowego w ramach ruchu wirowego można odnotować również w języku polskim - kręcić się wokót kogoś. Istnieją podstawy do stwierdzenia, że tego typu doświadczenie ludzkie jest dość uniwersalne.

Przyjrzyjmy się innemu przykładowi użycia czasownika ruchu wirowego w ramie pojęciowej uczuć. Czasownik крутить w połączeniach крутить роман/любовь uwypukla również nierozerwalny związek domeny źródłowej ruchu wirowego z domeną docelową uczuć, w tym wypadku odnoszącą się do zabiegania o czyjeś względy, interesowania się kimś, por.:

(10) Крутит роман с мужиком, который успешно морочит ей голову наличием несуществующей жены, которую он якобы не может бросить.

(11) Он носил прозвище Командор и крутил роман с продавщицей Раюсей.

(12) Когда-то крутил любовь с Сурковой , но очень быстро ее бросил. 
Odwzorowania między poszczególnymi elementami wzajemnej relacji "miłość" - „ruch wirowy” wyglądają następująco:

\section{RUCH WIROWY}

wirujący przedmiot

obracający przedmiotem 1

(współ)kręcący przedmiotem 2

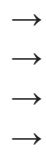

MItOŚć

uczucie miłości

osoba zakochana 1

osoba zakochana 2

Metafory pokazują nam, jak umysł człowieka ujmuje poszczególne aspekty doświadczenia związanego ze sferą uczuć, a zwłaszcza miłości. W tym wypadku metafora RUCH WIROWY daje nam możliwość spojrzenia na kwestie miłości jako czegoś, co jest wprawiane w ruch poprzez obrót wokół własnej osi. Natomiast rozumienie doświadczenia, w naszym przypadku - miłości, w kategoriach rzeczy upraszcza proces myślenia o tym doświadczeniu, gdyż dzięki jego ujęciu w konkretnych kategoriach, uzyskujemy możliwość jego identyfikacji, kategoryzacji. Tego typu metafory, w których podstawą doświadczeniową stają się rzeczy oraz substancje, Lakoff i Johnson nazywali metaforami ontologicznymi. Metafory ontologiczne kategoryzują sytuacje, czynności, stany, uczucia itd. w kategoriach przedmiotów fizycznych ograniczonych do pewnej powierzchni, objętości. W naszym przypadku miłość traktowana jest przez umysł jako przedmiot wprawiany w ruch przez osoby zaangażowane uczuciowo.

Porównując dwa poprzednie modele odpowiedniości pomiędzy elementami relacji metaforycznej, można zauważyć, że w każdym z nich inne elementy ulegają uwypukleniu. Cechą wspólną obu sytuacji jest ujmowanie uczucia miłości w kategoriach omawianego ruchu. Tym niemniej każda z powyższych sytuacji wypływa z nieco innej podstawy doświadczeniowej. Pierwsza - wynika z mającej podstawy kulturowo-społeczne fizycznej obserwacji z bliska osoby zakochanej (żywiącej takie uczucia) względem obiektu miłości (obiektu zainteresowania uczuciowego), będącego $\mathrm{w}$ centrum, czyli - na osi obrotowej, wokół której obywa się ruch zainteresowanej osoby. Druga - pozycjonuje doświadczenie uczuciowe w kategoriach przedmiotu wprawianego w ruch przez obu uczestników czynności. Pociąga to za sobą kształtowanie się naszego systemu pojęć i różnych sposobów ujmowania przez umysł czynności, stanów, uczuć w określonych ramach interpretacyjnych, w zależności od zamiaru uwypuklenia tego czy innego aspektu uczucia.

Jak już odnotowaliśmy, każdy przykład metafory naświetla pewne istotne elementy znaczeniowe pojęcia, dzięki czemu możemy z kolei uwypuklać bądź ukrywać inne aspekty danego pojęcia. Rozpatrzę na poniższych przykładach skonwencjonalizowane wyrażenie językowe (bc)кружить голову: 
(13) Кружить голову богатым барыням и молодым девушкам не мое дело [...].

(14) Это сейчас видно, что человек солидный, который не хочет кружить голову девочке понапрасну, а обращается к матери и [...].

(15) Но пришел „мастеровой человек”, улестил ласковыми, любовными словами, а отцу с матерью представил резоны, что-де „жить будем душа в душу, я, значит, работать, а она по хозяйству да около ребятишек", наговорил чудес просто личную развеселую жизнь, вскружил голову девке, обвенчался и увез в Питер.

(16) С выражением сытой снисходительности лениво посматривали они на сцену, а после ради забавы были готовы вскружить голову, затеять игру, развлечься, натешиться, чтобы затем навсегда забыть, выбросить, небрежно отодвинуть ногой, словно опустошенный яркий фантик, не задумываясь о раненой, изломанной ее душе.

Każde z wyrażeń metaforycznych zaprezentowanych do tej pory konceptualizuje uczucie miłości w ramie pojęciowej ruchu wirowego. Powyższe wyrażenia również stanowią przykład takiego ujęcia, niemniej wyrażenia te kładą nacisk na inną sytuację, inny przejaw uczuć. Wyrażenie (bc)кружить гоroby niesie ze sobą semantykę wzbudzenia w kimś uczucia miłości do siebie. Model odwzorowania odpowiedniości pomiędzy domeną źródłową i domeną docelową prezentuje się następująco:

\section{RUCH WIROWY}

wirowanie

wykonujący czynność kręcenia

\section{$\rightarrow \quad$ MIŁOść}

$\rightarrow$ uczucie (miłości)

$\rightarrow \quad$ osoba wzbudzająca uczucie (do siebie) osoba, u której wzbudza się uczucie

$\mathrm{W}$ zaprezentowanym przypadku model metaforyczny pokazuje, $\mathrm{w}$ jaki sposób następuje aktywizacja omawianej sfery uczuciowej. $Z$ tego punktu widzenia uczucie to może być wywoływane u osoby bez zaangażowania emocjonalnego wykonawcy. Wyobrażenie wprawiania głowy, stanowiącej centrum sfery uczuciowej, w ruch wirowy powoduje, że obracający się obiekt, tj. głowa jako centrum sfery uczuciowej, pozbawia osobę własnej woli, przejmuje nad nią kontrolę, w tym kontrolę nad uczuciami. Semantyka "kontroli" może stanowić część ogólniejszej metafory pojęciowej odnotowanej w czasownikach ruchu wirowego. Metafora KONTROLA TO RUCH WIROWY potwierdza swój status w użyciach czasowników bepmemъ i крymumъ, por.:

(17) Она ведь крутила мужиками как хотела и доила их как могла, и Гамаев не был исключением. А в выходные дни почти всегда, она ездила к Жене домой.

(18) Она с детства еще отличалась капризным, своенравным и настойчивым характером, вертела, как хотела, и барином и дворней - и барин исполнял все ее прихоти, а дворня подобострастно целовала у нее ручки и звала „барышней”. (19) Крутить мужчиной нужно незаметно, так, чтобы он сам думал, что он - хозяин и повелитель. 
Również tutaj odnajdujemy podstawę doświadczeniową opartą na prototypowej sytuacji, w której obiekt wprowadzany $\mathrm{w}$ ruch wirowy traci zdolność samokontroli, staje się przedmiotem czyjejś woli, obiektem oddziaływania. Jest to zakorzenione $\mathrm{w}$ fizycznym doświadczeniu i wynika z obserwacji obracającego się wokół własnej osi przedmiotu. Bezwładność postrzegana jest przez nasz umysł w kategoriach zależności, kontroli. Wykonawca czynności wprawiania $\mathrm{w}$ ruch okrężny drugiej osoby poniekąd panuje nad nią, zmusza do określonej postawy emocjonalnej. A zatem na poziomie metaforyzacji domena źródłowa ruchu okrężnego przenoszona jest na domenę docelową „kontroli, panowania nad kimś w sferze uczuciowej". Źródła leksykograficzne również potwierdzają takie znaczenie czasowników bepmemъ, крутить: 'распоряжаться кем-л. или чем-л. по своему усмотрению, заставлять действовать по своей воле' [Ефремова 2000: I, 161, 746].

Powrócę jednak do ujmowania badanego ruchu w kategoriach uczuć. Systematyczność pojawiania się pojęcia sfery uczuciowej konceptualizowanej jako ruch wirowy może powodować ukrycie pewnych aspektów tego pojęcia. W przykładach z wyrażeniem (вс)кружить голову ukryciu ulega stan emocjonalny wykonawcy czynności. Może to być postawa zaangażowana emocjonalnie bądź nie, a podejmowanie działania może wynikać z odmiennych pobudek, które mogą różnić się w zależności od intencji wykonawcy.

Wynika z tego, że system języka nie dysponuje precyzyjnymi narzędziami leksykalnymi do odtwarzania i uwypuklania pewnych aspektów życia ludzkiego, dlatego odwoływanie się do tego typu metafor jest jedyną możliwością przekazywania określonych, złożonych semantycznie pojęć. W związ$\mathrm{ku} \mathrm{z}$ tym metafora pojęciowa, opierając się na naszym doświadczeniu percepcyjnym, rysuje nam obraz, który bardziej do nas przemawia, gdyż jest wszechobecny w systemie językowym i przenika nasze myślenie, stając się integralną częścią naszego aparatu pojęciowego, przy pomocy którego wypowiadamy się, myślimy, tworzymy.

Aby nie ograniczać się wyłącznie do metafor pojęciowych odnoszących się do sfery uczuć, zwróćmy uwagę na metaforę UNIKANIE TO RUCH WIROWY. Pojęcie unikania może odnosić się do fizycznego unikania czegoś, wychodzenia z trudnych sytuacji życiowych, jak również może dotyczyć aktywności mentalnej, którą rozumiemy jako szerokiego rodzaju działalność umysłową człowieka, związaną z aktywnością werbalną i rozumową. Rozpatrzmy na przykład rosyjski czasownik выкручиваться, którego przenośne użycie odnosi się do sfery wychodzenia z trudnych sytuacji, unikania, omijania przeszkód. Przytoczę przykłady: 
(20) Выкручивался я из положения собственными силами, придумав довольно невинную оговорку в сноске.

(21) Он только врали выкручивался и под конец сам уже поверил в то, что у него на даче на веревке сидит звероящер.

(22) Он выкручивался как бес, чтобы не связывать себя обещанием, но когда удавалось выбить из него обещание, то он выполнял его, упорный, как осел, и нередко уже в одиночку.

(23) Ты, бывая даже пьяным, ловко выкручивался из самых критических положений.

Odwzorowania między poszczególnymi elementami wzajemnej relacji „unikanie” - „ruch wirowy” wyglądają w następujący sposób:

$\begin{array}{lll}\text { RUCH WIROWY } & \rightarrow & \text { UNIKANIE } \\ \text { ruch obrotowy (wykręcanie) } & \rightarrow & \text { wychodzenie z trudnej sytuacji } \\ \text { materiał } & \rightarrow & \text { trudna sytuacja } \\ \text { wykręcany przedmiot } & \rightarrow & \text { człowiek wychodzący z trudnej sytuacji }\end{array}$

Podstawę fizyczną stanowi doświadczenie oparte na sytuacji, w której osadzony w jakimś materiale przedmiot zostaje wyjęty dzięki czynności wykręcania. Czynność ta zazwyczaj wiąże się z pewnym wysiłkiem, co ma swoje przełożenie na pojęcie metaforyczne, w którym integralną część stanowi semantyka "trudności, problemów”. W tym miejscu należy zaznaczyć, że aktywizacja znaczenia wychodzenia z trudnej sytuacji uwarunkowana jest również semantyką samego czasownika, który, niezależnie od przynależności do grupy czasowników ruchu wirowego, niesie ze sobą również znaczenie ruchu postępowego. Istnienie metafory tego typu jest możliwe właśnie dzięki wyrażaniu przezeń znaczenia ruchu postępowego, czyli „zmiany położenia w przestrzeni”, co w ujęciu metaforycznym kształtuje pojęcie „zmiany sytuacji, wychodzenia z trudnych sytuacji”.

Wobec niemożności prezentacji wszystkich znanych metafor pojęciowych ze znaczeniem ruchu wirowego, przyjrzyjmy się ostatniemu przykładowi z czasownikami крутиться i вращ̧аться. Jak już wcześniej zaznaczyłem, domena źródłowa, w naszym przypadku - ruch wirowy, stanowi bazę konceptualną, dzięki której kształtowana jest domena docelowa. Tym razem rozpatrzę domenę docelową w kategoriach stanu mentalnego:

(24) Мысли крутились как вихрь в голове Раскольникова.

(25) В голове крутился последний вопрос, на который я не мог найти ответа.

(26) Он уже чувствовал, что идеи покинутого мира посещали его реже, вращаясь в голове медленнее и, ненаходя в окружающем ни отражения, ни сопротивления, не сходили на язык и умирали не плодясь. 
Jak słusznie odnotowują Lakoff i Johnson, kiedy jakaś rzecz wymyka się naszemu pojmowaniu w sposób wyraźny i określony bądź też nie ma określonych granic, to wówczas kategoryzujemy ją tak, aby miała własne granice [Lakoff, Johnson 1988: 48]. Do takich pojęć, niedających się swobodnie określić, możemy zaliczyć właśnie procesy mentalne człowieka, myśli, idee, refleksje itd. Pojęcia tego typu nie posiadają ściśle zarysowanych ram, dlatego człowiek rzutuje je na inną przestrzeń konceptualną, która pozwala na identyfikację tych pojęć, a to z kolei umożliwia ich kategoryzację. Istota metafor ontologicznych, jak już pisaliśmy, opiera się na rozumieniu pojęć abstrakcyjnych w kategoriach rzeczy i substancji. Ważną rolę odgrywa tutaj doświadczanie przedmiotów fizycznych, a zwłaszcza własnego ciała, będącego czymś odrębnym w stosunku do reszty świata. Dlatego widzimy świat jako coś, co jest poza nami, na zewnątrz. Jak piszą Lakoff, Johnson, „każdy z nas jest pojemnikiem z powierzchnią organiczającą i z orientacją typu w - poza. Przenosimy tę naszą orientację $\mathrm{w}$ - poza na inne przedmioty fizyczne, również ograniczone powierzchniami. Postrzegamy je jako pojemniki z przestrzenią wewnętrzną i zewnętrzną" [Lakoff, Johnson 1988: 52].

W ten sposób narzucamy otaczającej rzeczywistości wąskie ramy, wyznaczając pewne wyraźne granice i postrzegając rzeczy właśnie jako pojemniki. $\mathrm{Na}$ tej samej zasadzie dokonujemy rzutowania pojęć abstrakcyjnych. Przeanalizujmy powyższe przykłady. W tym wypadku procesy myślowe reprezentowane przez jednostki leksykalne - мысли, вопрос, идеu, ujmowane są $\mathrm{w}$ kategoriach przedmiotu, natomiast głowa traktowana jest jako pojemnik na przedmioty (myśli), w którym przechowywane są procesy myślowe ${ }^{3}$. Rozumienie stanów mentalnych jako rzeczy, a głowy w kategoriach pojemnika umożliwia ich lepszą identyfikację i możliwość przekazywania za pomocą metafory RUCH WIROWY dodatkowych znaczeń związanych z powtarzalnością, cyklicznością procesów myślowych. Zaprezentuję wzajemne odwzorowania elementów domeny źródłowej i domenty docelowej:

$\begin{array}{lll}\text { RUCH WIROWY } & \rightarrow & \text { PROCES MENTALNY } \\ \text { ruch obrotowy (cykliczność) } & \rightarrow & \text { powtarzalność procesu myślenia } \\ \text { pojemnik, w którym odbywa się ruch } & \rightarrow & \text { głowa } \\ \text { wirujące przedmioty } & \rightarrow & \text { myśli }\end{array}$

Znaczenie powtarzalności wynika z fizycznego doświadczenia ruchu wirowego, w którym obserwujemy cykliczność obrotów przedmiotu wokół

3 Takie samo podejście, ujmujące głowę jako pojemnik na stany i procesy mentalne, zaprezentowane jest również w artykule Doroty Filar i Bożeny Kotuły na przykładzie czasowników ruchu [Filar, Kotuła]. 
własnej osi. W tym wypadku uwypukleniu podlega właśnie cecha powtarzalności ruchu.

Podsumowując zaprezentowaną $\mathrm{w}$ skrócie problematykę metafor pojęciowych kształtujących się na bazie czasowników ruchu wirowego, należy stwierdzić, że istotną rolę $\mathrm{w}$ przenośnych znaczeniach metaforycznych odgrywa fizyczne doświadczanie przedmiotów przez człowieka. Sfera ludzkiego doświadczenia dostarcza nam bodźców do rzutowania pewnych aspektów domeny źródłowej na domenę docelową, dzięki czemu człowiek ujmuje pojęcia abstrakcyjne w kategoriach rzeczy fizycznych. W rezultacie pojęcia te stają się bliższe człowiekowi, podlegają kategoryzowaniu i dalszemu przetwarzaniu. Przedstawiony w artykule mały wycinek metafor pojęciowych stanowił tylko wstępną próbę prezentacji tego zjawiska na materiale czasowników ruchu okrężnego.

\section{Bibliografia}

Filar D., Kotuła B. Ruch jako domena źródtowa w metaforycznych nazwach stanów mentalnych (na podstawie polskich i słowackich czasowników ruchu), źródło elektroniczne: http:/ / doc player.pl/1352537-Ruch-jako-domena-zrodlowa-w-metaforycznych-nazwach-stanow -mentalnych.html (dostęp: 2017-08-09).

Jaynes J. 1976. The Origin of Consciousness in the Breakdown of the Bicameral Mind, Boston: Houghton Mifflin.

Kövecses Z. 2011. Język, umyst, kultura. Praktyczne wprowadzenie, Kraków: Universitas.

Lakoff G., Johnson M. 1988. Metafory w naszym życiu, Warszawa: Państwowy Instytut Wydawniczy.

Tokarski R. 2013. Światy za stowami. Wykłady z semantyki leksykalnej, Lublin: Wydawnictwo Uniwersytetu Marii Curie-Skłodowskiej.

Будаев Э. В. 2007. Становление когнитивной теории метафоры, „Лингвокультурология", t. 1, s. 16-32.

Ефремова Т. Ф. 2000. Новый словарь русского языка. Толково-словообразовательный, t. 1-2, Москва: Русский язык.

Круглякова В. А. 2010. Концептуализация вращения в испанском и русском языках, „Сuаdernos de Rusistica Espanola", nr 6, s. 29-54.

Круглякова В. А., Рахилина Е. В. 2010. Глаголы вращения: лексическая типология, [w:] В. П. Селегей (red.), Компьютерная лингвистика и интеллектуальные технологии, по материалам ежегодной Международной конференции "Диалог", t. 9 (16), s. 241-247.

Кузнецов С. А. (red.) 1998. Большой толковый словарь русского языка, Санкт-Петербург: Норинт.

Лакофф Д., Джонсон М. 1990. Метафоры, которыми мы живем, [w:] Н. Д. Арутюнова, М. А. Журинская (red.), Теория метафоры. Сборник статей, Москва: Прогресс, s. 387-415.

Маслова В. А. 2001. Лингвокультурология: Учеб. пособие для студ. высш. учеб. заведений, Москва: Издательский центр „Академия”. 
Национальный корпус русского языка, źródło elektroniczne: http:/ /www.ruscorpora.ru/ (dostęp 27.10.2017).

Приказчикова Е. В. 2009. Метафора как средство понимания текста, „Вестник МГОУ. Серия: Лингвистика", nr 2, s. 134-139.

Рикёр П. 1990. Живая метафора, [w:] Н. Д. Арутюнова, М. А. Журинская (red.), Теория метафроры. Сборник статей, Москва: Прогресс, s. 435-455. 